\title{
Influence of Different Environments on Germination Parameters and Seedling Morphology in Khaya senegalensis (Desr.) A. Juss (Meliaceae)
}

\author{
Beda Innocent Adji ${ }^{1,2^{*}}$, Sélastique Doffou Akaffou ${ }^{1}$, Kouadio Henri Kouassi ${ }^{1}$, \\ Yao Patrice Houphouet' ${ }^{1}$ Jerôme Duminil'3 , Sylvie Sabatier²
}

\begin{abstract}
${ }^{1}$ Université Jean Lorougnon Guédé, Agroforestry UFR, Departement for Seeds and Seedlings Production, Daloa, Côte d'Ivoire ${ }^{2}$ CIRAD, UMR AMAP, Montpellier, France AMAP, Université Montpellier, CIRAD, CNRS, INRA, IRD, Montpellier, France ${ }^{3}$ IRD, UMR-DIADE, Montpellier Cedex 5, France

Email: *adjibedainnocent@gmail.com
\end{abstract}

How to cite this paper: Adji, B.I., Akaffou, S.D., Kouassi, K.H., Houphouet, Y.P., Duminil, J. and Sabatier, S. (2020) Influence of Different Environments on Germination Parameters and Seedling Morphology in Khaya senegalensis (Desr.) A. Juss (Meliaceae). American Journal of Plant Sciences, 11, 1579-1600.

https://doi.org/10.4236/ajps.2020.1110114

Received: September 8, 2020

Accepted: October 23, 2020

Published: October 26, 2020

Copyright $\odot 2020$ by author(s) and Scientific Research Publishing Inc. This work is licensed under the Creative Commons Attribution International License (CC BY 4.0).

http://creativecommons.org/licenses/by/4.0/

\begin{abstract}
Khaya senegalensis is one of the largest and most majestic trees in Africa. Overexploited for its precious wood and medicinal values, the natural stands of this species are in danger of extinction in Côte d'Ivoire. Its sustainable management through regeneration techniques and assessment of its degree of adaptation to the changing climate is necessary. The aim of this study is to evaluate the effect of different environments on seedling germination and development in Khaya senegalensis. A total of 2160 seeds from different mother plants and 540 individuals from seed germination were selected and evaluated. The trials were conducted on three sites that were distinct by their microclimate (two nurseries in Côte d'Ivoire and one greenhouse in France). Analysis of variance showed that germination and morphology parameters were not influenced by the characteristics of the mother plants used $(\mathrm{p}>$ $0.05)$, but rather by the study sites $(\mathrm{P}<0.05)$. The stable and controlled greenhouse climate was more advantageous for latency time (12.66 \pm 0.80 days), germination delay (16.96 $96 \pm 0.54$ days), germination speed (19.66 \pm 2.95 days), germination duration (10.83 \pm 2.27 days) and germination rate $(88.88 \pm 7.97)$ with more vigorous sowing than the other two sites. The results showed in general that the higher the height of the seedlings, the thicker the diameter of the seedlings $(r=0.796)$ and the higher the number of leaves $(r=$ 0.946). This savannah species is native to the arid zones of Africa, but this study highlighted its adaptive potential to changing and different climates. These results are decision support tools for the regeneration of native pioneer forest species with high agroforestry potential and socio-economic impor-
\end{abstract}


tance such as Khaya senegalensis. This study could be extended to other species in order to restore disturbed ecosystems.

\section{Keywords}

Khaya senegalensis, Environments, Germination Parameters, Greenhouse, Côte d'Ivoire

\section{Introduction}

Forests play an important role in maintaining plant genetic resources, soil conservation, watershed stability, etc. [1]-[7]. In Africa, forests occupy almost 650 million hectares and provide foreign exchange and ecosystem services that meet the needs of local populations [8]-[13]. However, anthropogenic activities of all kinds (extensive, itinerant and migratory agriculture, bush fires, anarchic exploitation of certain resources, animal raving, etc.) and a galloping population are exerting a strong, non-discreet and increasing pressure on forest ecosystems [14] [15].

In sub-Saharan Africa, many species are threatened with extinction in forests due to overexploitation. Approximately $55 \%$ of plant species, of which $10 \%$ have disappeared in the wild [16] [17] [18]. Thus, species whose economic and socio-cultural activity plays a key role in meeting human health needs are the most threatened [14] [19] [20] [21]. In West Africa, access, exploitation and sustainable management of plant resources are a major issue for rural populations [22]. Indeed, sustainable management of forest resources means the management and use of forests and wooded areas in such a way and at such an intensity that they maintain their biological diversity, productivity, regeneration capacity, vitality and ability to satisfy, now and in the future, relevant ecological, economic and social functions at local, national and global levels, and that they do not cause damage to other ecosystems [23]. Thus, controlling the regeneration of local woody species remains the keystone of sustainable strategic management of arid and semi-arid vegetation types in West Africa [24].

In Côte d'Ivoire, the loss of forest cover has led to severe climate change [25] [10]. To solve this problem, forest management structures are trying to fill this gap with fast-growing exotic species such as Tectona grandis instead of local species. This drama, which is upsetting the local ecological balance, has been pointed out by the rural population. The Ivorian state therefore demands and prioritises forest management and agroforestry with local indigenous species.

Khaya senegalensis, commonly known as caillcédrat or Senegalese mahogany, is a tree of the Meliaceae family that can grow up to $35 \mathrm{~m}$ high with a very thick, scaly bark that ranges in colour from brownish to dark grey. Its trunk is very thick with a generally short and stocky appearance, up to $2 \mathrm{~m}$ in diameter, sometimes with a small serif at the base. Its leaves are arranged at the tips of the branches and form dense foliage [26] [27] [28] [29]. This species is native to the 
Sahelo-Sudanian and Sudanese zone of tropical Africa [26] [28] [30] [31] [32]. Khaya senegalensis is a species with multiple uses (pharmacopoeia, urban forestry, shade, firewood, timber, etc.) that is highly prized by rural populations [28] [29] [30] [32] [33] [34] [35] [36]. This species is subject to excessive and anarchic over-exploitation, exposing it to a loss of diversity that could eventually lead to its extinction [30] [37] [38].

In Côte d'Ivoire, the decline of Khaya sénégalensis stands is increasingly worrying. Its stands have become very rare in its area of distribution. Moreover, the effects of climate change do not favour the natural and rapid regeneration of this species. It is therefore necessary and urgent to develop artificial regeneration techniques in the current context of climate change in order to restore Khaya senegalensis populations on a large scale. The objective of this study is to assess the adaptation of Khaya senegalensis to different environments characterising the areas and ecosystems to be restored via germination and seedling vigour.

\section{Material and Method}

\subsection{Plant Material}

The plant material used is composed of seeds harvested from mature fruits of six (6) distinct mother plants, more than $550 \mathrm{~m}$ apart in a single stand of Khaya senegalensis and seedlings three (3) months old, from seeds harvested from under each mother plant. All seeds were collected from trees in good physiological condition and in good vigour at the experimental forest development station "Diabaté Kamonon" of the Centre National de Recherche Agronomique, in the Korhogo department of Côte d'Ivoire. The characteristics of the seed trees and the corresponding seeds are recorded in Table 1.

\subsection{Methods}

\subsubsection{Study Sites}

Testing was conducted from December 2018 to July 2019 at three (3) sites (Table 2). These sites are distinguished by their microclimate and are distributed in two (2) countries (Côte d'Ivoire "Korhogo: CNRA forest experimental

Table 1. Characteristics of Khaya senegalensis seeds used.

\begin{tabular}{|c|c|c|c|c|c|c|c|c|c|}
\hline \multirow{2}{*}{ Seeders } & \multirow{2}{*}{$\begin{array}{l}\text { DBH } \\
(\mathrm{cm})\end{array}$} & \multirow{2}{*}{$\begin{array}{c}\mathrm{H} \\
(\mathrm{m})\end{array}$} & \multirow{2}{*}{$\begin{array}{c}\text { Age } \\
\text { (year) }\end{array}$} & \multicolumn{2}{|c|}{ GPS coordinates } & \multirow{2}{*}{$\begin{array}{l}\text { Number } \\
\text { of seeds }\end{array}$} & \multicolumn{3}{|c|}{ Seed mass (g) } \\
\hline & & & & Longitude & Latitude & & Mini & Maxi & Mean \\
\hline 1 & 36.95 & 21 & 32 & $-5.5033 \mathrm{~W}$ & $9.5649 \mathrm{~N}$ & 360 & 0.1 & 0.27 & $0.16 \pm 0.04$ \\
\hline 2 & 91.72 & 31.5 & 43 & $-5.54454 \mathrm{~W}$ & $9.56562 \mathrm{~N}$ & 360 & 0.06 & 0.26 & $0.18 \pm 0.05$ \\
\hline 3 & 41.56 & 17.5 & 27 & $-5.54824 \mathrm{~W}$ & $9.56603 \mathrm{~N}$ & 360 & 0.06 & 0.32 & $0.21 \pm 0.07$ \\
\hline 4 & 39.17 & 21.5 & 28 & $-5.55008 \mathrm{~W}$ & $9.56476 \mathrm{~N}$ & 360 & 0.03 & 0.19 & $0.10 \pm 0.04$ \\
\hline 5 & 38.54 & 25 & 32 & $-5.5051 \mathrm{~W}$ & $9.56498 \mathrm{~N}$ & 360 & 0.09 & 0.28 & $0.17 \pm 0.05$ \\
\hline 6 & 36.78 & 17 & 32 & $-5.55064 \mathrm{~W}$ & $9.56345 \mathrm{~N}$ & 360 & 0.15 & 0.46 & $0.26 \pm 0.08$ \\
\hline
\end{tabular}

DBH = Diameter to Chest Height in centimeters; $\mathbf{H}=$ Height in meters; $\mathbf{W}=$ West; $\mathbf{N}=$ North; $\mathbf{M i n i}=$ Minimum in gram; $\mathbf{M a x i}=$ Maximum in gram . 
Table 2. Geographical location and characteristics of study sites [2] [39]-[49].

\begin{tabular}{|c|c|c|c|c|c|c|}
\hline $\begin{array}{c}\text { Sites or } \\
\text { environments }\end{array}$ & Coordinates & Vegetation & Climate & Temperature $\left({ }^{\circ} \mathrm{C}\right)$ & $\begin{array}{c}\text { Rainfall } \\
\text { (mm/year) }\end{array}$ & Soil type \\
\hline Korhogo (DeFo) & $\begin{array}{l}9^{\circ} 570^{\prime} 80556 " \mathrm{~N} ; \\
5^{\circ} 542^{\prime} 88889 " \mathrm{~W}\end{array}$ & $\begin{array}{l}\text { Clear forest (wooded } \\
\text { and grassy savannah) }\end{array}$ & Tropical dry & $26.6-35.7$ & $817-1216$ & $\begin{array}{l}\text { Ferruginous }(90 \%) \text { and Ferralitic } \\
(10 \%) \text { : superficial gravelly soil, deep } \\
\text { gravel with a heavy texture, low in } \\
\text { organic matter, highly desaturated. }\end{array}$ \\
\hline Daloa (UJLoG) & $\begin{array}{l}6^{\circ} 909^{\prime} 6363^{\prime \prime} \mathrm{N} ; \\
6^{\circ} 438^{\prime} 1157^{\prime \prime} \mathrm{W}\end{array}$ & Dense rain forest & $\begin{array}{c}\text { Wet tropical } \\
\text { (sub-equatorial) }\end{array}$ & $21-34$ & $1000-1900$ & $\begin{array}{c}\text { Ferralitic, deep, acidic and } \\
\text { desaturated in exchangeable bases, } \\
\text { rich in organic matter }\end{array}$ \\
\hline $\begin{array}{l}\text { Montpellier } \\
\text { (Greenhouse) }\end{array}$ & $\begin{array}{l}43^{\circ} 64981^{\prime} \mathrm{N} ; \\
3^{\circ} 86842^{\prime} \mathrm{W}\end{array}$ & in Greenhouse & in Greenhouse & $\begin{array}{l}24 \text { (Nighttime) - } \\
32 \text { (Daytime) }\end{array}$ & $\begin{array}{l}10 \mathrm{~cm}^{3} \text { per } \\
\text { week }\end{array}$ & $\begin{array}{c}\text { Mixture of Substrate Soil 1, } \\
\text { Neuhaus N2 Bio, Tref Rice CIRAD } \\
2 \text { and extra-silice sand from biot }\end{array}$ \\
\hline
\end{tabular}

$\mathbf{C}^{\bullet}=$ Degrees Celsius; $\mathbf{m m}=$ millimeter; Substrate 1 = Iron, trace elements, perlite and coconut fibre; Neuhaus N2 Bio = vegetable co-composting, blond and black peat; Tref Rice CIRAD 2 = clay, volcanic sand, perlite no. 2, coconut, Irish white peat and fine blond peat.

station (DeFo) and Daloa: Jean Lorougnon Guédé University (UJLoG)" and in a controlled environment in France "Montpellier: CIRAD 'Centre de Coopération International en Recherche Agronomique pour le Développement' Greenhouse number 8 of the Lavalette campus"). The localization and characteristics of the study sites are recorded in Table 2 .

\subsubsection{Setting up the Tests}

\section{Seed harvesting}

Mature fruit was harvested in December 2018, January 2019 and February 2019 from the mother plants with long wooden sticks with forks attached or by stoning the top of the tree with stones. Fruits and seeds were collected from under each tree, then the mature and dry fruits were peeled in order to extract the seeds. The seeds were divided into three (3) seed lots each destined for the sites described above for each seeder. A total of 2160 seeds were selected, including 120 seeds per seeder ( 6 seeders) for each study site (3: Korhogo, Daloa and Montpellier). So we have 120 seeds $\times 6$ mother plants $\times 3$ test sites $=2160$ seeds collected from Khaya sénégalensis.

\section{Test preparation and apparatus}

\section{Korhogo and Daloa Nursery}

Polyethylene bags measuring $20 \times 10 \mathrm{~cm}$ were filled with potting soil and arranged in one (1) block consisting of six (6) sub-blocks (Figure 1(b)). Each sub-block was labelled with the seeder's serial number and geographic coordinates and was intended for seed harvested on and under one (1) seeder. Each sub-block contains 60 soil bags prepared to receive two (2) seeds each. The seeds from each seeder were soaked in water for one day ( 24 hours) to accelerate germination and then seeded directly to a depth of $1.5 \mathrm{~cm}$ (by directing the lower end into the soil and the upper or wide end towards the surface) into the bags at a rate of two (2) seeds per bag. The phytosanitary treatment consisted of treating the seeds with granulated FURADAN to control rodents and the pre-leaves with 


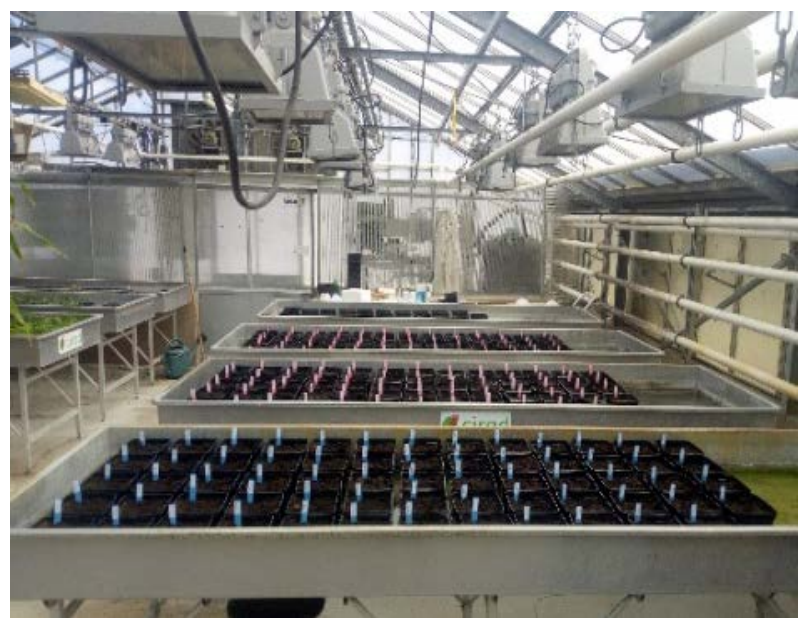

(a)

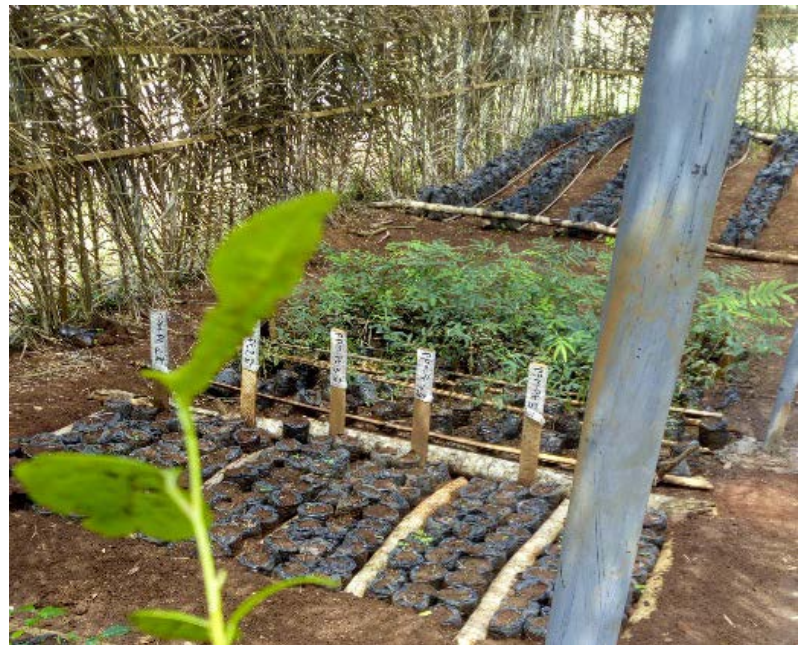

(b)

Figure 1. Image relating to the block system of trials set up in Montpellier greenhouse (a) and Daloa nursery (b).

DECIS to limit lava attacks. Nursery maintenance consisted of daily watering and manual weeding.

Greenhouse of the CIRAD of Montpellier

Polyester pots were filled with a mixture of potting compost of the above-mentioned composition. The pots were arranged in blocks and sub-blocks labelled in metal bins according to the same device used by Korhogo and Daloa (Figure 1(a)). The seed semi-piping was the same as at the other two sites. The phytosanitary treatment consisted of biological protection with BIOBEST against greenhouse whiteflies. Maintenance consisted of daily watering $\left(10 \mathrm{~cm}^{3}\right.$ per week).

\subsubsection{Data Collection}

\section{Germination parameters}

The Germination parameters evaluated concern 5 parameters, there are recorded in Table 3. 
Table 3. Germination parameters evaluated [24] [50]-[55].

\begin{tabular}{|c|c|}
\hline Parameters & Definitions \\
\hline 1-Waiting time or latency time & $\begin{array}{l}\text { The time elapsed between the half of all seeds and the } \\
\text { germination of a first seed }\end{array}$ \\
\hline 2-Germination delay & $\begin{array}{l}\text { The period between the sowing of each seed and the } \\
\text { appearance of each seedling }\end{array}$ \\
\hline 3-Germination speed & $\begin{array}{l}\text { The average time after which } 50 \% \text { of the seeds have } \\
\text { germinated }\end{array}$ \\
\hline 4-Spreading time or germination duration & $\begin{array}{l}\text { The period between the first seed germination and the } \\
\text { last seed germination }\end{array}$ \\
\hline 5-Germination rate & $\begin{array}{l}\text { The quotient of the number of seeds germinated by the } \\
\text { total number of seeds sown as a percentage (\%) }\end{array}$ \\
\hline
\end{tabular}

\section{Development parameters}

The parameters evaluated are recorded in Table 4.

All morphological (development) parameters were measured using a ruler graduated in centimetres and an electronic caliper in millimetres on a total of 540 seedlings ( 30 individuals per mother plant and per study site $=30 \times 6 \times 3=$ 540 seedlings).

\subsubsection{Data Analysis}

The statistical analyses were first performed using one-dimensional descriptive statistics, link analysis (linear regression, correlation and covariance) and multidimensional analysis (Principal Component Analysis "PCA") with XLSTAT 2020 version 7.5. The difference between the germination and morphology parameters was performed using a two-factor multivariate analysis (MANOVA) with the SAS software version 9.4. The Student-Newman-Keuls test at the 5\% threshold was used for post hoc comparisons.

\section{Results}

Germination of Khaya senegalensis is hypogeous with a long epicotyl reaching on average $6.33 \mathrm{~cm}$ long and $1.2 \mathrm{~mm}$ in average diameter at the collar (approximately 15 days after semi and five (5) days after the appearance of the coleoptile and radicle). The preleaves are almost blunt (absent or stunted petiole), opposite each other and generally identical in length and width. The coleoptile and radicle appear on average 10 days after semi. It is after the pre-leaves that phyllotaxis becomes alternate spiral. The seedling gradually develops simple leaves with longer and longer petioles until, at 11 weeks, the appearance of imperipinnate compound leaves which, over time, develop into paripinnate compound leaves.

\subsection{Germination and Development Parameters by Study Site or Environment}

\subsubsection{Environment 1: Korhogo \\ Germination parameters}


Table 4. Development parameters evaluated.

\begin{tabular}{ll}
\hline \multicolumn{1}{c}{ Parameters } & \multicolumn{1}{c}{ Definitions } \\
\hline 1-Height of the seedlings (HtPl) & $\begin{array}{l}\text { The length between the collar and the apex of the } \\
\text { seedling }\end{array}$ \\
2-Diameter at the collar of the seedlings (Dcol) & The base thickness of the main stem of the seedling \\
3-Number of leaves (NbreFe) & $\begin{array}{l}\text { The number of leaf organs built or present on the } \\
\text { main stem of the seedling }\end{array}$ \\
T-Leaf length (LgFe) & $\begin{array}{l}\text { The length from the beginning of the petiole to the } \\
\text { end of the main vein of the leaf blade of each leaf } \\
\text { present on the main stem of the seedling }\end{array}$ \\
5-Leaf width (LaFe) & $\begin{array}{l}\text { The width of the leaf blade or to the line perpendicular } \\
\text { to the main vein in the centre of the leaf blade }\end{array}$ \\
6-Length of internodes (LgEntr) & $\begin{array}{l}\text { The length connecting two nodes or between two } \\
\text { points of successive insertions of organs or leaf scars, } \\
\text { from the base to the apex of the seedling }\end{array}$ \\
\hline
\end{tabular}

In Korhogo the results showed that germination latency times were 21 days, 22 days, 22 days, 21 days and 21 days respectively for seed trees 1, 2, 3, 4, 5 and 6. Germination delay for seed trees 1, 2, 3, 4, 5 and 6 varied respectively from 21 to 37 days around a mean of $28.09 \pm 4.09$ days, from 22 to 47 days around a mean of $31.10 \pm 6.53$ days, from 22 to 49 days around a mean of $34,03 \pm 6.59$ days, from 21 to 48 days around a mean of $33.51 \pm 6.62$ days, from 21 to 40 days around a mean of $29.62 \pm 4.76$ days and from 21 to 48 days around a mean of $34.09 \pm 6.07$ days. Germination speed were 29 days, 46 days, 38 days, 39 days, 38 days and 35 days respectively for seeders $1,2,3,4,5$ and 6 . Germination duration were 16 days, 24 days, 27 days, 27 days, 19 days and 27 days for seeders 1, 2, 3, 4, 5 and 6 respectively. Finally, germination rates of seeds from the Korhogo study site were $93.33 \%, 58 \%, 70 \%, 71.66 \%, 58.33 \%$ and $100 \%$ respectively for seed companies $1,2,3,4,5$ and 6 .

Development parameters

Comparison of the morphological characteristics of the seedlings from each seed company (Table 5) indicates a significant difference between seed company seedlings for each characteristic assessed $(\mathrm{P}<0.05)$.

\subsubsection{Environment 2: Daloa}

\section{Germination parameters}

At Daloa, germination waiting times for seed trees 1, 2, 3, 4, 5 and 6 were 10 days, 18 days, 13 days, 15 days, 14 days and 16 days respectively. Germination delay ranged from 10 to 22 days around a mean of $17.13 \pm 2.763$ days, from 18 to 47 days around a mean of $30.2 \pm 6.70$ days, from 13 to 38 days around a mean of $26.26 \pm 7.04$ days, from 15 to 44 days around a mean of $25.1 \pm 6.797$ days, from 14 to 30 days around a mean of $19.5 \pm 3.097$ days and from 16 to 24 days around a mean of $20.3 \pm 2.423$ days for seeders $1,2,3,4,5$ and 6 respectively. Germination speeds were 22 days, 47 days, 38 days, 38 days, 44 days, 30 days and 24 days for seeders 1, 2, 3, 4, 5 and 6 respectively. Germination duration were 12 days, 29 
Table 5. Influence of seed companies on seedling development characteristics in Korhogo.

\begin{tabular}{|c|c|c|c|c|c|c|}
\hline Seeders & $\mathrm{HtPl}(\mathrm{cm})$ & $\operatorname{Dcol}(\mathrm{mm})$ & $\mathrm{NbrFe}$ & $\operatorname{LgFe}(\mathrm{cm})$ & $\mathrm{LaFe}(\mathrm{cm})$ & LgEntr $(\mathrm{cm})$ \\
\hline Seeder-1 & $17.25 \pm 2.62 \mathrm{~b}$ & $2.01 \pm 0.51 \mathrm{ab}$ & $5.86 \pm 0.79 b$ & $9.56 \pm 0.51 \mathrm{ab}$ & $2.9 \pm 0.31 \mathrm{~b}$ & $1.98 \pm 0.61 b$ \\
\hline Seeder-2 & $17.78 \pm 1.56 \mathrm{~b}$ & $2.73 \pm 0.47 \mathrm{a}$ & $5.85 \pm 0.85 b$ & $10.81 \pm 0.42 \mathrm{ab}$ & $3.8 \pm 0.18 \mathrm{a}$ & $2.63 \pm 0.56 \mathrm{ab}$ \\
\hline Seeder-3 & $18.68 \pm 2.42 \mathrm{ab}$ & $2.69 \pm 0.53 \mathrm{a}$ & $6.57 \pm 0.88 \mathrm{ab}$ & $13.2 \pm 0.66 \mathrm{a}$ & $3.82 \pm 0.34 \mathrm{a}$ & $3.52 \pm 0.71 \mathrm{a}$ \\
\hline Seeder-4 & $16.96 \pm 2.87 \mathrm{~b}$ & $1.41 \pm 0.49 b$ & $5.95 \pm 0.72 b$ & $11.21 \pm 0.72 \mathrm{ab}$ & $3.74 \pm 0.17 a$ & $3.05 \pm 0.48 \mathrm{ab}$ \\
\hline Seeder-5 & $17.85 \pm 3.05 \mathrm{ab}$ & $2.85 \pm 0.56 \mathrm{a}$ & $6.8 \pm 0.83 \mathrm{a}$ & $8.7 \pm 0.43 b$ & $4.02 \pm 0.35 \mathrm{a}$ & $1.58 \pm 0.63 b$ \\
\hline Seeder-6 & $19.62 \pm 2.44 \mathrm{a}$ & $2.42 \pm 0.68 \mathrm{a}$ & $6.95 \pm 0.82 \mathrm{a}$ & $12.2 \pm 0.81 \mathrm{ab}$ & $3.01 \pm 0.13 b$ & $4.13 \pm 0.57 \mathrm{a}$ \\
\hline $\operatorname{Pr}>F$ & 0.0001 & 0.0031 & 0.047 & 0.0021 & 0.011 & 0.0382 \\
\hline
\end{tabular}

For each character, values with the same letters are not statistically different at the $5 \%$ threshold.

days, 25 days, 25 days, 29 days, 16 days and 8 days respectively for seeders 1, 2, 3, 4,5 and 6. Seed germination rates were $87 \%, 70 \%, 80 \%, 63.33 \%, 65 \%$ and $95 \%$ for seed companies 1, 2, 3, 4, 5 and 6 respectively.

Development parameters

At Daloa, comparison of seedling development characteristics (Table 6) indicates statistically significant variability among seedlings of seed companies for all characteristics assessed at Daloa $(\mathrm{P}<0.05)$.

\subsubsection{Environment 3: Montpellier (Greenhouse)}

Germination parameters

In the CIRAD greenhouse at the Lavalette campus (controlled environment), results showed that germination latencies were 12 days, 12 days, 13 days, 16 days, 10 days and 13 days respectively for seeders 1, 2, 3, 4, 5 and 6. Germination delay for seed from seeders $1,2,3,4,5$ and 6 varied respectively from 12 to 34 days around a mean of $16.25 \pm 2.63$ days, from 12 to 21 days around a mean of $16.315 \pm 2.56$ days, from 13 to 20 days around a mean of $16.238 \pm 2.278$ days, from 16 to 25 days around a mean of $19.655 \pm 3.066$ days, from 10 to 20 days around a mean of $16.526 \pm 3.24$ days, and from 13 to 21 days around a mean of $16.82 \pm 2.52$ days. Germination speeds were 34 days, 17 days, 14 days, 19 days, 16 days and 18 days respectively for seeders $1,2,3,4,5$ and 6 . Germination durations were 22 days, 9 days, 7 days, 7 days, 9 days, 10 days and 8 days for seeders $1,2,3,4,5$ and 6 respectively. Germination rates were 50\%, 88.33\%, 100\%, $96.66 \%, 98.33 \%$ and $100 \%$ for seeders $1,2,3,4,5$ and 6 respectively.

Development parameters

Comparison of the morphological characteristics of seedlings from each seeder (Table 7) shows that the seedlings are all different from one seeder to another for each characteristic assessed at Montpellier $(\mathrm{P}<0.05)$.

\subsection{Synthesis of Germination and Development}

\subsubsection{Germination Parameters}

Figure 2 provides an overview of all germination parameters observed at the 
Table 6. Influence of seeders on seedling development characteristics in Daloa.

\begin{tabular}{ccccccc}
\hline Seeders & HtPl $(\mathrm{cm})$ & Dcol $(\mathrm{mm})$ & NbrFe & LgFe $(\mathrm{cm})$ & LaFe $(\mathrm{cm})$ & LgEntr $(\mathrm{cm})$ \\
\hline Seeder-1 & $23.5 \pm 2.11 \mathrm{ab}$ & $3.01 \pm 0.33 \mathrm{ab}$ & $7.86 \pm 0.64 \mathrm{~b}$ & $10.36 \pm 0.28 \mathrm{~b}$ & $3.01 \pm 0.41 \mathrm{~b}$ & $3.56 \pm 0.62 \mathrm{ab}$ \\
Seeder-2 & $21.48 \pm 3.36 \mathrm{~b}$ & $3.73 \pm 0.41 \mathrm{a}$ & $7.85 \pm 0.57 \mathrm{~b}$ & $11.08 \pm 0.18 \mathrm{~b}$ & $3.8 \pm 0.12 \mathrm{ab}$ & $3.41 \pm 0.31 \mathrm{ab}$ \\
Seeder-3 & $26.68 \pm 3.51 \mathrm{ab}$ & $3.69 \pm 0.52 \mathrm{a}$ & $8.57 \pm 0.42 \mathrm{ab}$ & $14.31 \pm 0.41 \mathrm{a}$ & $4.32 \pm 0.31 \mathrm{a}$ & $4.05 \pm 0.41 \mathrm{a}$ \\
Seeder-4 & $27.56 \pm 2.17 \mathrm{a}$ & $2.41 \pm 0.21 \mathrm{~b}$ & $7.95 \pm 0.47 \mathrm{~b}$ & $9 \pm 0.37 \mathrm{~b}$ & $3.42 \pm 0.52 \mathrm{ab}$ & $3.02 \pm 0.19 \mathrm{ab}$ \\
Seeder-5 & $24.85 \pm 3.08 \mathrm{ab}$ & $3.85 \pm 0.36 \mathrm{a}$ & $8.8 \pm 0.35 \mathrm{a}$ & $10.6 \pm 0.24 \mathrm{~b}$ & $3.61 \pm 0.27 \mathrm{ab}$ & $2.94 \pm 0.34 \mathrm{ab}$ \\
Seeder-6 & $25.63 \pm 3.01 \mathrm{ab}$ & $3.42 \pm 0.18 \mathrm{a}$ & $8.95 \pm 0.82 \mathrm{a}$ & $11.8 \pm 0.29 \mathrm{~b}$ & $3.97 \pm 0.23 \mathrm{ab}$ & $2.32 \pm 0.26 \mathrm{~b}$ \\
Pr $>\mathrm{F}$ & $\mathbf{0 . 0 0 7 1}$ & $\mathbf{0 . 0 1 1 1}$ & $\mathbf{0 . 0 0 5 1}$ & $\mathbf{0 . 0 0 1}$ & $\mathbf{0 . 0 0 8 3}$ & $\mathbf{0 . 0 0 2 3 1}$
\end{tabular}

For each character, values with the same letters are not statistically different at the $5 \%$ threshold.

Table 7. Influence of seeders on the development characteristics of seedlings in Montpellier greenhouse.

\begin{tabular}{ccccccc}
\hline Seeders & HtPl $(\mathrm{cm})$ & Dcol $(\mathrm{mm})$ & NbrFe & $\operatorname{LgFe}(\mathrm{cm})$ & $\operatorname{LaFe}(\mathrm{cm})$ & $\operatorname{LgEntr}(\mathrm{cm})$ \\
\hline Seeder-1 & $27.75 \pm 1.25 \mathrm{ab}$ & $4.01 \pm 0.14 \mathrm{ab}$ & $8.86 \pm 0.71 \mathrm{~b}$ & $10.33 \pm 0.45 \mathrm{ab}$ & $3.6 \pm 0.51 \mathrm{~b}$ & $3.6 \pm 0.42 \mathrm{~b}$ \\
Seeder-2 & $27.98 \pm 2.33 \mathrm{ab}$ & $4.73 \pm 0.43 \mathrm{a}$ & $8.85 \pm 0.34 \mathrm{~b}$ & $11.46 \pm 0.42 \mathrm{ab}$ & $4.3 \pm 0.25 \mathrm{a}$ & $4.23 \pm 0.31 \mathrm{a}$ \\
Seeder-3 & $28.68 \pm 1.61 \mathrm{ab}$ & $4.69 \pm 0.61 \mathrm{a}$ & $9.57 \pm 0.19 \mathrm{ab}$ & $12.36 \pm 0.28 \mathrm{a}$ & $4.56 \pm 0.17 \mathrm{a}$ & $3.36 \pm 0.11 \mathrm{~b}$ \\
Seeder-4 & $26.36 \pm 1.17 \mathrm{~b}$ & $3.41 \pm 0.23 \mathrm{~b}$ & $8.95 \pm 0.18 \mathrm{~b}$ & $9.6 \pm 0.29 \mathrm{~b}$ & $3.43 \pm 0.19 \mathrm{~b}$ & $3.58 \pm 0.17 \mathrm{~b}$ \\
Seeder-5 & $27.75 \pm 3.12 \mathrm{ab}$ & $4.85 \pm 0.21 \mathrm{a}$ & $9.8 \pm 0.15 \mathrm{a}$ & $9.5 \pm 0.14 \mathrm{~b}$ & $3.43 \pm 0.27 \mathrm{~b}$ & $3.89 \pm 0.19 \mathrm{ab}$ \\
Seeder-6 & $29.72 \pm 1.45 \mathrm{a}$ & $4.42 \pm 0.51 \mathrm{a}$ & $9.95 \pm 0.27 \mathrm{a}$ & $10.63 \pm 0.47 \mathrm{ab}$ & $3.96 \pm 0.36 \mathrm{ab}$ & $4.52 \pm 0.27 \mathrm{a}$ \\
Pr $>\mathrm{F}$ & $\mathbf{0 . 0 4 6}$ & $\mathbf{0 . 0 1 1 4}$ & $\mathbf{0 . 0 3 3 1}$ & $\mathbf{0 . 0 0 0 1}$ & $\mathbf{0 . 0 2 1}$ & $\mathbf{0 . 0 0 1}$ \\
\hline
\end{tabular}

For each character, values with the same letters are not statistically different at the $5 \%$ threshold.
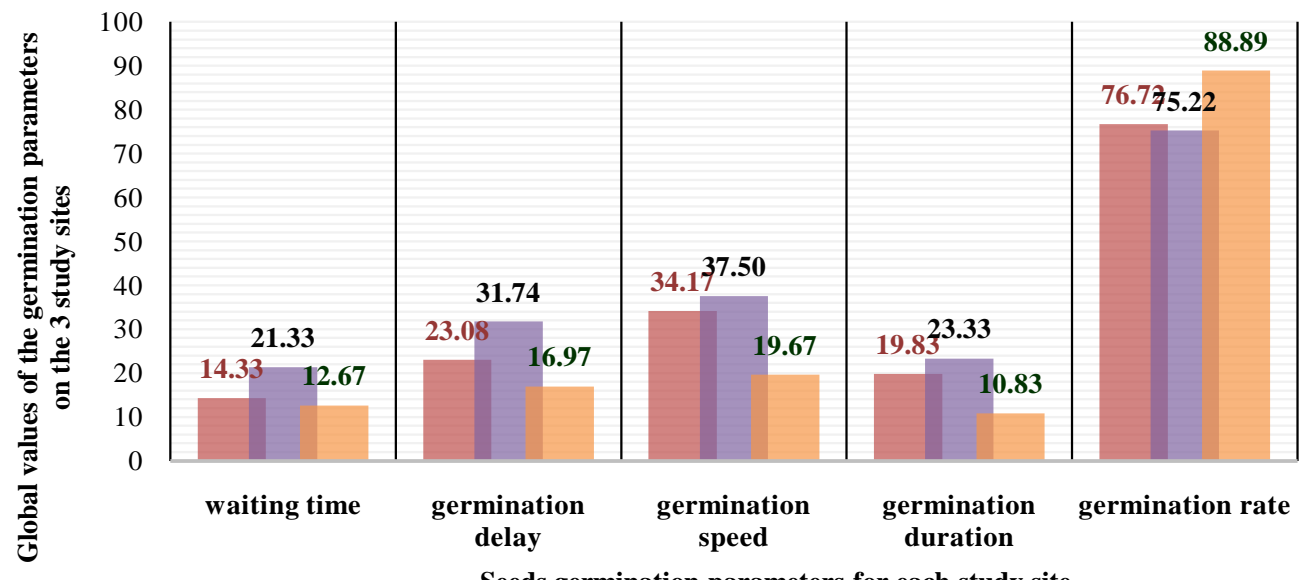

Seeds germination parameters for each study site

$\square$ Daloa $\quad$ Korhogo $\square$ Montpellier (greenhouse)

Figure 2. Comparison of each germination parameters for all 3 study sites.

three study sites. This figure indicates that overall, only the germination rate was higher in Montpellier glasshouse and that Korhogo recorded the highest values for the four (4) other germination parameters (waiting time, germination delay, germination speed and germination duration) observed. 


\section{Influence of seeders}

The analysis of variance (Table 8) shows overall that the seed company does not influence seed germination parameters because all observed variables are statistically identical from one seed company to another $(p>0.05)$ for all three sites.

\section{Influence of environments}

The analysis of variance (Table 9) indicates a significant difference between study sites for the parameters waiting time, germination delay, germination speed and germination spread $(P<0.05)$. However, it indicates that the germination rate is statistically the same in all study sites $(\mathrm{P}>0.05)$.

Table 10 shows in general for all study sites a strong positive correlation between

Table 8. Influence of seeders on germination parameters of Khaya senegalensis.

\begin{tabular}{cccccc}
\hline Seeders & waiting time & $\begin{array}{c}\text { germination } \\
\text { delay }\end{array}$ & $\begin{array}{c}\text { germination } \\
\text { speed }\end{array}$ & $\begin{array}{c}\text { germination } \\
\text { duration }\end{array}$ & $\begin{array}{c}\text { germination } \\
\text { rate }\end{array}$ \\
\hline Seeder-1 & $14.33 \pm 3.38 \mathrm{a}$ & $20.49 \pm 3.80 \mathrm{a}$ & $28.33 \pm 3.48 \mathrm{a}$ & $16.66 \pm 2.90 \mathrm{a}$ & $76.77 \pm 13.51 \mathrm{a}$ \\
Seeder-2 & $17.33 \pm 2.90 \mathrm{a}$ & $25.87 \pm 4.78 \mathrm{a}$ & $36.66 \pm 9.83 \mathrm{a}$ & $20.66 \pm 6.01 \mathrm{a}$ & $72.11 \pm 8.81 \mathrm{a}$ \\
Seeder-3 & $16.00 \pm 3.00 \mathrm{a}$ & $25.50 \pm 5.15 \mathrm{a}$ & $30.00 \pm 8.00 \mathrm{a}$ & $19.66 \pm 6.36 \mathrm{a}$ & $83.33 \pm 8.82 \mathrm{a}$ \\
Seeder-4 & $17.33 \pm 1.85 \mathrm{a}$ & $26.09 \pm 4.03 \mathrm{a}$ & $34.00 \pm 7.64 \mathrm{a}$ & $21.66 \pm 6.36 \mathrm{a}$ & $77.21 \pm 10.01 \mathrm{a}$ \\
Seeder-5 & $15.00 \pm 3.21 \mathrm{a}$ & $21.88 \pm 3.96 \mathrm{a}$ & $28.00 \pm 6.43 \mathrm{a}$ & $15.00 \pm 2.64 \mathrm{a}$ & $73.88 \pm 12.37 \mathrm{a}$ \\
Seeder-6 & $16.66 \pm 2.33 \mathrm{a}$ & $23.74 \pm 5.27 \mathrm{a}$ & $25.66 \pm 4.97 \mathrm{a}$ & $14.33 \pm 6.33 \mathrm{a}$ & $98.33 \pm 1.66 \mathrm{a}$ \\
Pr > F & $\mathbf{0 . 9 5 9 8}$ & $\mathbf{0 . 9 2 5 5}$ & $\mathbf{0 . 8 7 7 5}$ & $\mathbf{0 . 8 8 4 8}$ & $\mathbf{0 . 4 9 0 8}$ \\
\hline
\end{tabular}

For each character, values with the same letters are not statistically different at the $5 \%$ threshold.

Table 9. Influence of environment on germination variable of Khaya senegalensis.

\begin{tabular}{cccccc}
\hline $\begin{array}{c}\text { study site or } \\
\text { environments }\end{array}$ & waiting time & $\begin{array}{c}\text { germination } \\
\text { delay }\end{array}$ & $\begin{array}{c}\text { germination } \\
\text { speed }\end{array}$ & $\begin{array}{c}\text { germination } \\
\text { duration }\end{array}$ & $\begin{array}{c}\text { germination } \\
\text { rate }\end{array}$ \\
\hline Korhogo & $21.33 \pm 0.21 \mathrm{a}$ & $31.74 \pm 1.03 \mathrm{a}$ & $37.50 \pm 2.26 \mathrm{a}$ & $23.33 \pm 1.94 \mathrm{a}$ & $75.22 \pm 7.22 \mathrm{a}$ \\
Daloa & $14.33 \pm 1.16 \mathrm{~b}$ & $23.08 \pm 2.07 \mathrm{~b}$ & $34.16 \pm 4.26 \mathrm{a}$ & $19.83 \pm 3.70 \mathrm{a}$ & $76.72 \pm 5.20 \mathrm{a}$ \\
$\begin{array}{c}\text { Montpellier } \\
\text { greenhouse })\end{array}$ & $12.66 \pm 0.80 \mathrm{~b}$ & $16.96 \pm 0.54 \mathrm{c}$ & $19.66 \pm 2.95 \mathrm{~b}$ & $10.83 \pm 2.27 \mathrm{~b}$ & $88.88 \pm 7.97 \mathrm{a}$ \\
\begin{tabular}{c} 
Pr $>\boldsymbol{F}$ \\
\hline
\end{tabular} & $\mathbf{0 . 0 0 0 1}$ & $\mathbf{0 . 0 0 0 1}$ & $\mathbf{0 . 0 0 3 5}$ & $\mathbf{0 . 0 1 6}$ & $\mathbf{0 . 3 3 4 3}$ \\
\hline
\end{tabular}

For each character, values with the same letters are not statistically different at the $5 \%$ threshold.

Table 10. Correlation matrix (Pearson) of germination parameters for all study sites.

\begin{tabular}{|c|c|c|c|c|c|}
\hline Variables & waiting time & $\begin{array}{c}\text { germination } \\
\text { delay }\end{array}$ & $\begin{array}{c}\text { germination } \\
\text { speed }\end{array}$ & $\begin{array}{l}\text { germination } \\
\text { duration }\end{array}$ & $\begin{array}{c}\text { germination } \\
\text { rate }\end{array}$ \\
\hline waiting time & 1 & & & & \\
\hline germination delay & 0.899 & 1 & & & \\
\hline germination speed & 0.622 & 0.787 & 1 & & \\
\hline germination duration & 0.554 & 0.797 & 0.935 & 1 & \\
\hline germination rate & -0.269 & -0.325 & -0.747 & -0.634 & 1 \\
\hline
\end{tabular}

Values in bold are different from 0 at significance level alpha $=0.05$. 
germination speed and germination duration and between waiting time and germination delay. It indicates a positive correlation between waiting time and germination speed, germination delay and germination speed and germination duration. However the matrix shows a strong negative correlation between germination rate and germination speed then germination duration.

\subsubsection{Development Parameters}

\section{Influence of seeders}

The analysis of variance of the morphological characteristics of the seedlings from each seeder (Table 11) indicates a statistical similarity between the variables Height $(\mathrm{HtPl})$, diameter at collar (Dcol), number of leaves (NbreFe) and internode lengths (LgEntr) of the seedlings $(\mathrm{P}>0.05)$. However, the length $(\mathrm{LgFe})$ and width $(\mathrm{LaFe})$ of the leaves of the seedlings are all different between seedlings $(\mathrm{P}<0.05)$.

\section{Influence of environments}

Overall, the results in Table 12 show that morphology parameters behave statistically differently from one environment to another $(P<0.05)$, except for leaf length and width, which are all the same regardless of the study site $(\mathrm{P}<0.05)$.

Table 11. Influence of seeders on morphological parameters of Khaya senegalensis seedlings.

\begin{tabular}{|c|c|c|c|c|c|c|}
\hline Seeders & $\mathrm{HtPl}(\mathrm{cm})$ & $\operatorname{Dcol}(\mathrm{mm})$ & NbreFe & $\operatorname{LgFe}(\mathrm{cm})$ & $\mathrm{LaFe}(\mathrm{cm})$ & LgEntr $(\mathrm{cm})$ \\
\hline Seeder-1 & $22.83 \pm 3.04 \mathrm{a}$ & $3.01 \pm 0.57 \mathrm{a}$ & $7.52 \pm 0.88 \mathrm{a}$ & $10.08 \pm 0.26 b$ & $3.17 \pm 0.21 \mathrm{~b}$ & $3.05 \pm 0.53 \mathrm{a}$ \\
\hline Seeder-2 & $22.41 \pm 2.98 \mathrm{a}$ & $3.73 \pm 0.57 \mathbf{a}$ & $7.51 \pm 0.88 \mathrm{a}$ & $11.12 \pm 0.18 b$ & $3.96 \pm 0.17 \mathrm{ab}$ & $3.42 \pm 0.46 \mathrm{a}$ \\
\hline Seeder-3 & $24.68 \pm 3.05 \mathrm{a}$ & $3.65 \pm 0.58 \mathrm{a}$ & $8.23 \pm 0.88 \mathrm{a}$ & $13.29 \pm 0.56 \mathbf{a}$ & $4.23 \pm 0.22 \mathbf{a}$ & $3.64 \pm 0.21 \mathrm{a}$ \\
\hline Seeder- 4 & $23.62 \pm 3.35 \mathrm{a}$ & $2.41 \pm 0.57 \mathbf{a}$ & $7.61 \pm 0.88 \mathbf{a}$ & $9.94 \pm 0.66 b$ & $3.53 \pm 0.11 \mathrm{ab}$ & $3.22 \pm 0.18 a$ \\
\hline Seeder-5 & $23.48 \pm 2.94 \mathrm{a}$ & $3.85 \pm 0.57 \mathrm{a}$ & $8.47 \pm 0.88 \mathrm{a}$ & $9.60 \pm 0.55 b$ & $3.69 \pm 0.17 \mathrm{ab}$ & $2.80 \pm 0.67 \mathrm{a}$ \\
\hline Seeder-6 & $24.99 \pm 2.93 \mathrm{a}$ & $3.42 \pm 0.57 \mathbf{a}$ & $8.62 \pm 0.88 a$ & $11.54 \pm 0.47 b$ & $3.04 \pm 0.31 \mathrm{ab}$ & $3.66 \pm 0.68 \mathrm{a}$ \\
\hline $\operatorname{Pr}>F$ & 0.9882 & 0.5071 & 0.8892 & 0.0014 & 0.0441 & 0.7933 \\
\hline
\end{tabular}

HtPl: Height of the seedlings; Dcol: Diameter at the collar of the seedlings; NbreFe: Number of leaves; LgFe: Leaf length; LaFe: Leaf width; LgEntr: Length of internodes; $\mathbf{c m}$ : centimetres; mm: millimetres. For each character, values with the same letters are not statistically different at the $5 \%$ threshold.

Table 12. Influence of environments on morphological parameters of Khaya senegalensis.

\begin{tabular}{|c|c|c|c|c|c|c|}
\hline $\begin{array}{l}\text { Study site or } \\
\text { Environments }\end{array}$ & $\mathrm{HtPl}(\mathrm{cm})$ & Dcol (mm) & NbreFe & $\mathrm{LgFe}(\mathrm{cm})$ & $\mathrm{LaFe}(\mathrm{cm})$ & LgEntr $(\mathrm{cm})$ \\
\hline Daloa & $24.95 \pm 0.90 \mathrm{~b}$ & $3.35 \pm 0.22 b$ & $8.33 \pm 0.20 b$ & $11.19 \pm 0.73 \mathrm{a}$ & $3.68 \pm 0.18 \mathrm{a}$ & $3.22 \pm 0.24 \mathrm{ab}$ \\
\hline Korhogo & $18.02 \pm 0.39 c$ & $2.35 \pm 0.22 c$ & $6.33 \pm 0.20 c$ & $10.94 \pm 0.67 \mathrm{a}$ & $3.54 \pm 0.19 \mathrm{a}$ & $2.81 \pm 0.38 \mathrm{~b}$ \\
\hline $\begin{array}{l}\text { Montpellier } \\
\text { (greenhouse) }\end{array}$ & $28.04 \pm 0.45 \mathrm{a}$ & $4.35 \pm 0.22 \mathrm{a}$ & $9.33 \pm 0.21 \mathrm{a}$ & $10.64 \pm 0.45 \mathrm{a}$ & $3.88 \pm 0.19 \mathrm{a}$ & $3.86 \pm 0.18 a$ \\
\hline $\operatorname{Pr}>F$ & 0.0001 & 0.0001 & 0.0001 & 0.8310 & 0.4829 & 0.0481 \\
\hline
\end{tabular}

HtPl: Height of the seedlings; Dcol: Diameter at the collar of the seedlings; NbreFe: Number of leaves; LgFe: Leaf length; LaFe: Leaf width; LgEntr: Length of internodes; $\mathbf{c m}$ : centimetres; $\mathrm{mm}$ : millimetres. For each character, values with the same letters are not statistically different at the $5 \%$ threshold. 
The covariance (Table 13) indicates in general for all seedlings from each seedling distributed over the 3 study sites, a strong correlation between height and diameter at the collar of the seedlings, then between height and number of leaves of the seedlings. This matrix also indicates a strong positive correlation between the crown diameter and the number of leaves of the seedlings.

Figure 3 shows the projection of environments and morphological parameters for all seedlings in PCA 1 - 2 (biplot). The analysis of the matrix of factor weights allowed the extraction of two components that explain $100 \%$ of the variability and are therefore very relevant in explaining the total variation between the morphological characteristics of the seedlings and the environments. Plan 1 2 is characterized by eigenvalues of $86.87 \%$ for axis $\mathrm{F} 1$ and $13.13 \%$ for axis F2. The different descriptors contributing to the formation of the first (F1) and second component (F2) show two groups. The first group consists of Montpellier (greenhouse) by higher heights, collar diameters, leaf counts, leaf widths and

Table 13. Correlation matrix (Pearson) of morphological characteristics of seedlings for all study sites.

\begin{tabular}{ccccccc}
\hline Variables & HtPl (cm) & Dcol (mm) & NbrFe & LgFe $(\mathrm{cm})$ & LaFe $(\mathrm{cm})$ & LgEntr $(\mathrm{cm})$ \\
\hline $\mathrm{HtPl}(\mathrm{cm})$ & 1 & & & & & \\
$\mathrm{Dcol}(\mathrm{mm})$ & $\mathbf{0 . 7 9 6}$ & 1 & & & & \\
$\mathrm{NbrFe}$ & $\mathbf{0 . 9 4 6}$ & $\mathbf{0 . 8 7 6}$ & 1 & & & \\
$\mathrm{LgFe}(\mathrm{cm})$ & 0.032 & 0.106 & 0.033 & 1 & & \\
$\mathrm{LaFe}(\mathrm{cm})$ & 0.336 & 0.496 & 0.351 & 0.467 & 1 & \\
$\mathrm{LgEntr}(\mathrm{cm})$ & 0.561 & 0.498 & 0.526 & 0.417 & 0.111 & 1 \\
\hline
\end{tabular}

HtPl: Height of the seedlings; Dcol: Diameter at the collar of the seedlings; NbreFe: Number of leaves; LgFe: Leaf length; LaFe: Leaf width; LgEntr: Length of internodes; $\mathbf{c m}$ : centimetres; mm: millimetres. Values in bold are different from 0 at significance level alpha $=0.05$.

\section{Biplot (axis F1 and F2 : 100,00 \%)}

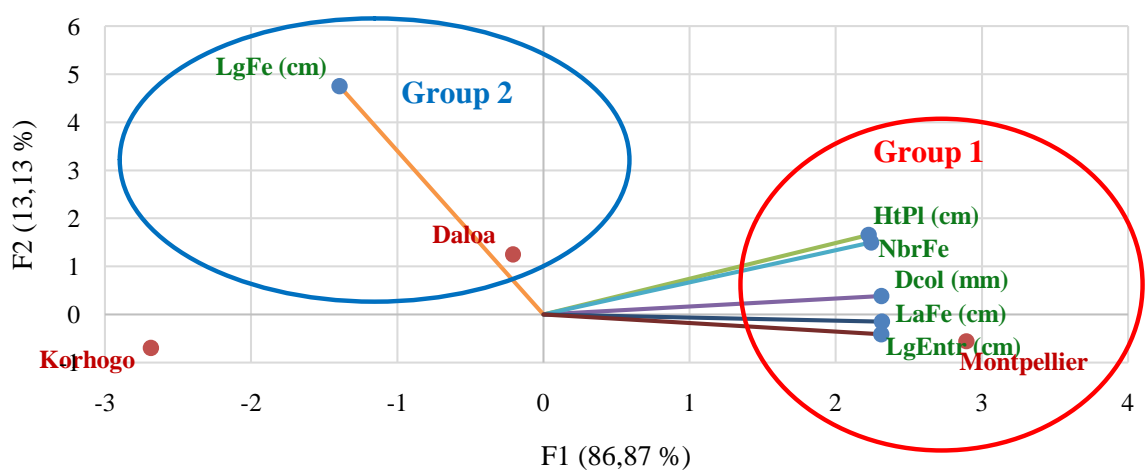

Variables actives Observations actives

Figure 3. Projection of localities and morphological parameters observed in PCA Plan 1 2 as a function of axis type. HtPl: Height of the seedlings; Dcol: Diameter at the collar of the seedlings; NbreFe: Number of leaves; LgFe: Leaf length; LaFe: Leaf width; LgEntr: Length of internodes; $\mathrm{cm}$ : centimetres; mm: millimetres. 
internode lengths of seedlings than Daloa and Korhogo. The second group consists of Daloa, which is characterized by higher seedling leaf widths.

\section{Discussion}

\subsection{Germination Parameters}

The results showed that the germination of Khaya senegalensis is hypogeous with almost stalkless pre-leaves. The seedling emits over time leaves with longer and longer petioles until it develops a compound leaf. Indeed at the very young stage (one week after germination), the plant still depends on the starch contained in the seed. The reserve contained in the embryo is used to emit opposite leaves without petiole at the beginning then some leaves ( 2 to 5 leaves) alternate spiral with increasingly long petioles. The seedling becomes independent following the disappearance of the embryo and the appearance of leaves composed imperipenate then later composed paripenate (authentic organogenesis of the species). The seedling expresses its normal development only after reaching the compound leaf stage. In fact, the cost of operating and building its normal structure is high and therefore requires continuous adaptation.

In Korhogo, the minimum latency was 21 days and was observed in seed trees 1, 4, 5 and 6; in Daloa the minimum latency was 10 days (seed tree 1), the maximum latency was 18 days (seed tree 2) and in a controlled environment (greenhouse) the minimum latency was also 10 days (seed tree 5) with a maximum of 16 days (seed tree 4 ). This minimum germination delay potential is not related to the type of seed tree since it differs from one seed tree to another for each study site. However, this difference in latency time between study sites could be related to soil richness and local climate type. Indeed in Korhogo the seeds were sown in a ferruginous soil subjected to a dry tropical climate unlike Daloa (ferralitic soil and humid tropical climate) and in Greenhouse (mixture of substrate rich in mineral elements with a very stable climate without fluctuation). However, some authors in Niger and in Burkina Faso obtained lower latency times (5 to 7 days) on the same soil type as Korhogo, but with 4 species of Combretaceae (Combretum glutinosum, Combretum micranthum, Combretum nigrians and Guiera senegalensis) [24] [56].

The results showed that the average minimum germination delay of seeds in Korhogo was 28.09 days (seeder 1), 17.13 days (seeder 1) in Daloa and 16.23 days (seeder 3 ) in a controlled environment just before seeder 1 (16.25 days). Overall, seeds sown in greenhouses have a reduced germination delay, unlike seeds sown in Korhogo. This is explained by the stable and constant temperature throughout the experiment $\left(28^{\circ} \mathrm{C}\right.$ to $32^{\circ} \mathrm{C}$ day and $22^{\circ} \mathrm{C}$ to $24^{\circ} \mathrm{C}$ night $)$. The delays are longer in Korhogo because of the unstable and deregulated climate subject to temperature fluctuation observed in recent years [38]. Indeed a very high heat without regular water supply limits the delay and even damages the seeds. Authors have found the same case for germination of Faidherbia albida [57]. Indeed, several studies have shown the effect of the climate or climatic zone of 
origin, soil, mother trees and soil poverty on germination, growth and morphological development of seedlings [58]-[66]. Seedlings 1 seems to be characterized by a relatively short seedling delay regardless of the study site, probably due to its thin-shelled seeds facilitating emergence from the seed coat. Indeed, a rigid fruit shell would limit the capacity for rapid germination through pericarpic dormancy [67]. Studies have found pericarpal dormancy in Pterocarpus angolensis and Pterocarpus santalinus respectively [68] [69]. The minimum germination speed in Korhogo was 29 days (seeder 1), 22 days (seeder 1) in Daloa and 14 days (seeder 3) in Montpellier. Half of the seeds sown germinated faster in Daloa and Montpellier because of the relatively high and humid temperatures and the richness of the soil. Indeed, while light allows plants to develop (elaboration of structure), heat favours growth (dry matter gain) and thus rapid seed dormancy [70] [71]. The minimum period between the first germination and the last germination was 16 days in Korhogo (seeder 1), 8 days (seeder 6) in Daloa and 7 days (seeder 3 ) in a controlled environment. These germination times are short despite the fact that the seeds have not been treated beforehand as was the case with Pterocarpus erinaceus [54], Parkia biglobosa [72], Pistacia vera [73], Albizzia lebbek, Albizzia procera, Peltophorum pterocarpum and Acacia auriculiformis and Leucaena leucocephala [74]. As for the germination rate, it was higher with seeds from seed tree 6 (100\%) and lower with seeds from seed tree 2 (58\%) in Korhogo; in Daloa this rate was high for seed tree 6 (95\%) and lower for seed tree $4(63.33 \%)$ and in the greenhouse it was higher for seed trees $3(100 \%)$ and 6 $(100 \%)$ and lower for seed tree $1(50 \%)$. Seeder 6 has a higher rate than the other 5 seeders across all study sites because of its visibly larger, uniform and heavier seeds. The seeds of the other seed companies have smaller and more varied seed sizes (mass, length, width and thickness). A germination test calibrating seed size is necessary to confirm this fact and to guide the choice of seed that can limit germination failure rates or even the choice of marketable seed. Overall, Korhogo environment recorded longer waiting times, delays and germination duration with slower germination speed than other study sites. This is related to the poor soil and climate of the area. High germination rates were recorded in the Montpellier greenhouse and it should be noted that $100 \%$ germination rates were obtained in Korhogo and Montpellier. In fact this species is native to the Guinean-Sudanian and Sudano-Sahelian savannah zone [33] [34] [37] [38] [75] and the climate of Korhogo and the greenhouse have the same environmental conditions as this zone (Guinean-Sudanian and Sudano-Sahelian). Authors had obtained similar germination rates in the same area with another species (Parkia biglobosa) originating from the same climate [76]. The analysis of variance showed that all seeds from the seed growers had almost the same germination behaviour from one site to another. This is clearly explained by the similarity of the intra variability in seed size from one seed company to another. However, Student's test indicates that each site significantly influences all the observed parameters except germination rate, which statistically presents the same distributions from one site to another. This is similarly due to the environment (climates 
and soil type) to which the seeds are subjected for germination [58]-[66]. The correlation matrix generally indicates a strong positive relationship between latency and germination delay $(r=0.899)$ and germination speed $(r=0.622)$; meaning that the longer it takes for the first germination to occur, the slower the germination speed and the longer the germination delay. It also indicates a strong positive correlation between germination delay and germination speed $(\mathrm{r}$ $=0.787)$ then germination duration $(r=0.797)$; this indicates that the shorter the germination delay, the faster the germination speed and the shorter the germination period. This correlation matrix also indicates a strong positive correlation between germination speed and germination durée $(r=0.935)$, which means that the faster the germination speed, the shorter the germination spread. However, the same matrix shows a negative correlation between germination rate and germination speed $(\mathrm{r}=-0.747)$ and then germination duration $(\mathrm{r}=-0.634)$. This highlights the fact that the higher the germination rate, the slower the speed and the lower the spread of germination.

\subsection{Development Parameters}

The analysis of variance indicated a significant difference between study sites for the majority of morphological characteristics observed in the seedlings $(\mathrm{P}<$ 0.05). At Korhogo the mean height of the seedlings was $18.02 \mathrm{~cm}$ and the mean diameter at the collar of the seedlings was $2.35 \mathrm{~mm}$. These values are lower than those obtained in the same environment (climate and soil type) in Niger with Guiera senegalensis (mean height $25.8 \mathrm{~cm}$ and mean diameter $3.22 \mathrm{~mm}$ ) after 100 days [24] and in Côte d'Ivoire (Haut Bandama Reserve) in 3 months with Pterocapus erinaceus (mean height $40 \mathrm{~cm}$ and mean diameter $4.35 \mathrm{~mm}$ ) [54]. In detail, the student test showed that morphological characters of seedlings differed from one locality to another except for leaf length and width $(P>0.05)$. However, when considering seedlings from one seeder to another for all 3 sites combined, this test indicated that leaf length and width differed statistically $(\mathrm{P}<$ 0.05). Indeed, seeds from each seedling were separated and repeated at each site, hence the no influence of the environment effect on certain development parameters; however, seeds have different characteristics from one seedling to another, which can lead to variations in seedling morphology from one seedling to another. In fact, depending on the environmental conditions of the environment (temperature, sunshine, hygrometry, soil, etc.), seedlings vary the morphology (length and width) of their leaves in order to adapt and better capture sunlight for efficient photosynthetic activation. Studies [58]-[66] have already shown the effect of climate, soil, mother trees and soil poverty on the germination, growth and morphological development of several plant species. The pearson matrix showed overall a strong positive correlation between seedling height and crown diameter $(r=0.796)$ and leaf count. This means that an increase in height leads to an increase in the diameter and number of leaves of the seedlings. It also indicates a strong correlation between crown diameter and leaf count $(r=0.876)$. This means that as the crown diameter increases, the number 
of leaves on the seedlings increases. The principal component analysis showed that the Montpellier glasshouse is related to the highest morphological characteristics. Indeed, a stable and controlled environment increases the height, diameter, number of leaves, length of leaves and internodes of the seedlings. Since the seedlings are in optimal conditions, organogenesis takes place without limiting factors.

\section{Conclusion}

This study carried out on germination and seedling development of Khaya senegalensis in different environments showed that the environment (climate and soil type) influences germination and seedling development in Khaya senegalensis $(\mathrm{P}<0.05)$. However, the characteristics of the mother trees (seed source) sampled did not have a significant effect on germination and seedling development $(\mathrm{P}>0.05)$. It appears from this study that the stable and controlled environment (greenhouse) and the environment characterized by a humid tropical climate are more favourable for artificial regeneration of stands in Khaya senegalensis. This savannah species is native to the arid zones of Africa, but this study highlighted its adaptive potential to changing and different climates. We conclude from this study that it is important to take into account the climatic characteristics of the environments to be restored. This study could be extended to other species for the sustainable management of disturbed areas and ecosystems.

\section{Statement of Credit Author's Contribution}

Beda Innocent Adji: Conceptualization, Methodology, Supervision, Software, Formal Analysis, Resources, Data Retention. Sélastique Doffou Akaffou: Project Administration, Methodology, Resources, Data Retention, Supervision, Writing original project, Research and acquisition of funding. Yao Patrice Houphouet: Methodology. Kouadio Henri Kouassi: Project administration, Writing original project, Research and acquisition of funding. Jerôme Duminil: Project administration, Resources, Writing original project, Research and acquisition of financing. Sylvie Sabatier: Project Administration, Methodology, Resources, Data Retention, Supervision, Writing original project, Research and acquisition of funding.

\section{Acknowledgements}

This study was financed by the MESRS (Ministry of Higher Education and Scientific Research) of Côte d'Ivoire, the AFD (Agence Française de Développement) and the IRD (Institut de Recherche Pour le Développement) within the framework of PRESeD-CI 2 (Renewed Partnership for Research for Development in Côte d'Ivoire) and C2D (Debt Reduction Contract) of the AMRUGE-CI project (Support for the Modernization and Reform of Universities and Grandes Ecoles of Côte d'Ivoire). The authors are very grateful to the CIRAD (Centre de 
Coopération International de Recherche Agronomique pour le Développement) for providing a greenhouse (controlled environment) and the technical equipment necessary for the conduct of this study.

\section{Conflicts of Interest}

All the authors agree to the publication of these results and declare that they have no conflict of interest.

\section{References}

[1] Houndonougbo, J.S.H., Kassa, B., Mensah, S., Salako, V.K., Glèlè, K.R. and Assogbadjo, A.E. (2020) A Global Systematic Review on Conservation and Domestication of Parkia biglobosa (Jacq.) R. Br. ex G. Don, an Indigenous Fruit Tree Species in Sub-Sahara African Traditional Parklands: Current Knowledge and Future Directions. Genetic Resources and Crop Evolution, 67, 1051-1066.

https://doi.org/10.1007/s10722-020-00892-w

[2] Bruno, H., Anatole, K.N., N’klo, O., Assandé, A., Fabrice, B., Brahima, C., Doua-Bi, Y., Koffi, Y., Koffi, K.J.C., Konaté, I., Tiéoulé, F., Wourro, F., Zo-Bi, I.C. and Louppe, D. (2020) The Long-Term Performance of 35 Tree Species of Sudanian West Africa in Pure and Mixed Plantings. Forest Ecology and Management, 468, 118-171. https://doi.org/10.1016/j.foreco.2020.118171

[3] Dumenu, W.K. (2019) Assessing the Impact of Felling/Export Ban and CITES Designation on Exploitation of African Rosewood (Pterocarpus erinaceus). Biological Conservation, 236, 124-133. https://doi.org/10.1016/j.biocon.2019.05.044

[4] Segla, N.K., Rabiou, H., Adjonou, K., Moussa, B.M., Saley, K., Radji, R.A., Kokutse, A.D., Bationo, A.B., Mahamane, A. and Kokou, K. (2016) Population Structure and Minimum Felling Diameter of Pterocarpus erinaceus Poir in Arid and Semi-Arid Climate Zones of West Africa. South African Journal of Botany, 103, 17-24. https://doi.org/10.1016/j.sajb.2015.09.005

[5] FAO (2014) State of the World's Forests (SOFO). Enhancing the Socioeconomic Benefits from Forests, Putting People at the Centre. 133.

[6] Mbowa, C., Chhinb, S., Samboua, B. and Skolec, D. (2013) Potential of Dendrochronology to Assess Annual Rates of Biomass Productivity in Savanna Trees of West Africa. Dendrochronologia, 31, 41-51. https://doi.org/10.1016/j.dendro.2012.06.001

[7] Choat, B., Jansen, S., Brodribb, T.J., Cochard, H., Delzon, S., Bhaskar, R., Bucci, S.J., Field, T.S., Gleason, S.M., Hacke, U.G., Jacobsen, A.L., Lens, F., Maherali, H., Martinez-Vilalta, J., Mayr, S., Mencuccini, M., Mitchell, P.J., Nardini, A., Pittermann, J., Pratt, R.B., Sperry, J.S., Westoby, M., Wright, I.J. and Zanne, A.E. (2012) Global Convergence in the Vulnerability of Forests to Drought. Nature, 491, 752-755. https://doi.org/10.1038/nature11688

[8] IPGRI (1999) Vers une approche régionale des ressources génétiques forestières en Afrique sub-saharienne. Recensement Général de la Population et de l'Habitat Sahélien. Actes du premier atelier régional de formation sur la conservation et l'utilisation durable des ressources génétiques forestières en Afrique de l'ouest, Afrique forestière. CIRAD/GILLSS/CORAF/CTA/DESC/FAO/UNEP/UNSO, Ouagadougou, Burkina Faso, 229.

[9] Kamari, P., Otaghvaria, A.M., Govindapyari, H., Bahuguna, M. and Uniyal, P. (2009) Some Ethno-Medically Important of India. International Medical Aromatic of Plant, 1, 18-22. 
[10] Piba, C., Koulibaly, D., Goetze, D., Porembski, S. and Traoré, D. (2011) Diversité et importance sociale des espèces médicinales conservées dans les agrosystèmes cacaoyers au Centre-Ouest de la Côte d'Ivoire. Annales de Botanique de l Afrique de POuest, 7, 80-96.

[11] Kumar, P. and Lalramnghinglova, H. (2011) India with Special Reference to an Indo-Burma Hotspot Region. Ethnobotany Research \& Applications, 9, 379-420. https://doi.org/10.17348/era.9.0.379-420

[12] De Wasseige, C., Marcken, P., Bayol, N., Hiol, H.F., Mayaux, P. and Desclée, B. (2012) Les forêts du bassin du Congo. État des forêts 2010. Office des publications de l'Union européenne, Luxembourg, $276 \mathrm{p}$.

[13] Sosef, M., Dauby, G., Blach-Overgaard, A., van der Burgt, X., Catarino, L. and Damen, T. (2017) Exploring the Floristic Diversity of Tropical Africa. BMC Biology, 15, 15. https://doi.org/10.1186/s12915-017-0356-8

[14] Kossi, N.S., Kossi, A., Abdou, R.R., Adzo, D.K., Kouami, K., Rabiou, H., Pouwisawe, K., Babou, A.B. and Ali, M. (2015) Importance Socio-Economique de Pterocarpus erinaceus poir au togo. European Scientific Journal, 11, 199-217.

[15] Marie-louise, A.A., Sincère, K., Delphine, D.N. and Blaise, M.M. (2019) Structure des peuplements et potentiel de domestication de Parkia biglobosa dans la région de Tandjilé-Ouest (Tchad). International Journal of Biological and Chemical Science, 13, 219-236. https://doi.org/10.4314/ijbcs.v13i1.19

[16] Sinsin, B., Eyog, M.O., Assogbadjo, A.E., Gaoue, G.O. and Siandouwirou, T. (2004) Dendrometric Characteristics as Indicators of Pressure on Afzelia africana Sm. Dynamic Changes in Trees Found in Different Climatic Zones of Benin. Biodiversity and Conservation, 13, 1555-1570. https://doi.org/10.1023/B:BIOC.0000021328.56517.46

[17] Glèlè, K.R., Assogbadjo, A.E., Sinsin, B. and Pelz, D. (2009) Structure spatiale et régénération naturelle de Pterocarpus erinaceus Poir en zone Soudanienne au Benin. Revue Ivoirienne des Sciences et Technologies, 13, 199-212.

[18] Maréchal, C., Cawoy, V., Coquyt, C., Dauby, G., Dessein, S., Douglas-Hamilton, I., Dupain, J., Fischer, E., Obang, D.F., Groom, Q., Henshel, P., Jeffery, K.J., Korte, L., Lewis, S.L., Lubunu, S., Maisels, F., Melletti, M., Ngouffo, R., Ntore, S., Palla, F., Scholte, P., Sonke, B., Stevart, T., Stoffelen, P., Van Den Broeck, D., Walters, G. and Williamson, E.A. (2014) Conservation et Gestion de la biodiversité. In Etat des Forets 2013. 67-96.

[19] Touré, Y. (2001) Etude des potentialités agro forestières de la multiplication et des usages de Pterocarpus erinaceus Poir en zone soudanienne du Burkina Faso. Mémoire IDR, $89 \mathrm{p}$.

[20] Eba', A.R., Lescuyer, G., Gouhouo, P.J. and Moulende, F.T. (2013) Etude de l'importance économique et sociale du secteur forestier et faunique dans les Etats d'Afrique Centrale, Cas du Cameroun. Rapport d'étude CIFOR, 316 p.

[21] Maazou, R., Rabiou, H., Issiaka, Y., Abdou, L., Saidou, I.S. and Mahamane, A. (2017) Influence de l'occupation des terres sur la dynamique des communautés végétales en zone Sahélienne, cas de la commune rurale de Dantchandou (Niger). International Journal of Biological and Chemical Science, 11, 79-92. https://doi.org/10.4314/ijbcs.v11i1.7

[22] Drabo, I., Ilboudo, F., Tallet, B., Quesnel, A. and Marchal, J.Y. (2013) Dynamique des populations, disponibilités en terres et adaptation des régimes fonciers, le Burkina Faso, une étude de cas. CICRED, Paris, FAO, Rome, 114 p.

[23] Leroy, M., Derroire, G., Vendé, J. and Leménager, T. (2015) La gestion durable des 
forêts tropicales. De l'analyse critique du concept à l'évaluation environnementale des dispositifs de gestion. Bois et Forets des Tropiques, 86-87.

[24] Amani, M.M., Inoussa, I., Dan Guimbo, A., Mahamane, M., Saadou, A. and Lykke, A.M. (2015) Germination et croissance de quatre espèces de Combretaceae en pépinière. Tropicultura, 33, 135-145.

[25] Akaffou, S.D., Kouamé, K.A., Gore, B.B.N., Abessika, Y.G., Kouassi, K.H., Hamon, P., Sabatier, S. and Duminil, J. (2019) Effect of the Seeds Provenance and Treatment on the Germination Rate and Plants Growth of Four Forest Trees Species of Côte d'Ivoire. Journal of Forestry Research, 73, 87-90. https://doi.org/10.1007/s11676-019-01064-y

[26] Nikiema, A. and Pasternak, D. (2008) Khaya senegalensis (Desr.) A. Juss. PROTA (Plant Resources of Tropical Africa/Ressources végétales de l'Afrique tropicale). 43-56.

[27] Belem, B., Olsen, C.S., Theilade, I., Bellefontaine, R., Guniko, S., Lykke, A.M., Diallo, A. and Boussim, J.I. (2008) Identification des arbres hors forêt préférés des populations du Sanmatenga (Burkina Faso). Bois et Forêts des Tropiques, 298, 53-64.

[28] Obafèmi, A.F.L., Yacinthe, A., Abiodoun, P.O., Erick, V.B.A. and Anatole, L. (2015) Etude bibliographique de trois plantes antidiabétiques de la flore béninoise, Khaya senegalensis (Desr) A. Juss (Meliaceae), Momordica charantia Linn (Cucurbitaceae) et Moringa oleifera Lam (Moringaceae). International Journal of Biological Sciences, 9, 2682-2700. https://doi.org/10.4314/ijbcs.v9i5.38

[29] Issa, I., Wala, K., Dourma, M., Atakpama, W., Kanda, M. and Akpagana, K. (2017) Valeur ethno botanique de l'espèce Khaya senegalensis (Desr.) A. Juss (meliaceae) auprès des populations riveraines de la chaîne de l'Atacora au Togo. Revue Marocaine des Sciences Agronomiques et Vétérinaire, 6, 64-72.

[30] Sokpon, N. and Ouinsavi, C. (2004) Gestion des plantations de Khaya senegalensis au Bénin. Bois et Forêts des Tropiques, 279, 37-46.

[31] Kokou, K., Atato, A., Bellefontaine, R., Kokuste, A. and Caballé, G. (2006) Diversité des forêts denses sèches du Togo (Afrique de l'Ouest). Revue d Ecologie-La Terre et la Vie, 61, 225-246.

[32] Ulrich, G.B.D., Charle, J.J., Loumeto, F., Jacques, C., Gonmadje, D. and McKey, D. (2019) Des confusions entre espèces préjudiciables à la gestion durable des essences forestières, l'exemple des acajous d'Afrique (Khaya, Meliaceae). Bois et Forêts des Tropiques, 339, 17-32. https://doi.org/10.19182/bft2019.339.a31714

[33] Sylla, S.N., Samba, R.T., Neyra, M., Ndoye, I., Giraud, E., Willems, A., de Lajudie, P., and Dreyfus, B. (2002) Phenotypic and Genotypic Diversity of Rhizobia Nodulating Pterocarpus erinaceus and P. lucens in Senegal. Systematic and Applied Microbiology, 25, 572-583. https://doi.org/10.1078/07232020260517715

[34] Ouedraogo, A., Adjima, T., Hahn-Hadjali, K. and Guinko, S. (2006) Diagnostic de l'état de dégradation des peuplements de quatre espèces ligneuses en zone soudanienne du Burkina Faso. Sécheresse, 17, 485-491.

[35] Gaoue, O.G. and Ticktin, T. (2008) Impacts of Bark and Foliage Harvest on Khaya senegalensis (Meliaceae) Reproductive Performance in Benin. Journal of Applied Ecology, 45, 34-40. https://doi.org/10.1111/j.1365-2664.2007.01381.x

[36] Kando, L.F. (2012) Evaluation et caracterisation des cailcedrats (Khaya senegalensis (desr.) a. juss) d'alignement de la commune de ouagadougou. Mémoire de fin de cycle. $70 \mathrm{p}$.

[37] Guédjé, N.M., Fokunang, N.C., Jiofack, T.R.B. and Dongmo, F.R. (2010) Opportu- 
nités d'une exploitation soutenue des plantes médicinales dans l'aménagement forestier. International Journal of Biological and Chemical Sciences, 4, 1346-1372.

http://ajol.info/index.php/ijbcs https://doi.org/10.4314/ijbcs.v4i4.63070

[38] Mapongmetsem, P.M., Nkongmeneck, B.A., Rongoumi, G., Dongock, D.N. and Dongmo, B. (2011) Impact des systèmes d'utilisation des terres sur la conservation de Vitellaria paradoxa Gaerten. F. (Sapotaceae) dans la région des savanes soudano-guinéennes. International Journal of Environmental Studies, 68, 851-872. https://doi.org/10.1080/00207233.2011.587259

[39] Guillaumet, J.L., Adjanohoun, E., Avenard, J.M., Eldin, M., Girard, G., Circoulin, J., Toucheboeuf, P. and Perraud, A. (1971) Le milieu naturel de Côte d'Ivoire. Mémoires ORSTOM, 50, 156-264.

[40] Perraud, A. (1971) Les sols. In, Le milieu naturel de la Côte d'Ivoire. Mémoires ORSTOM, 50, 69-390.

[41] Louppe, D. and Ouattara, N. (1996) Les arboretums d'espèces locales en Nord Côte d'Ivoire. IDEFOR, 14 p. http://agritrop.cirad.fr/581418

[42] Bornand, M., Barthès, J.P. and Bonfils, P. (1999) Carte des pédopaysage de la région languédoc-Roussillon-Département de l'Hérault. INRA Montpellier. 2 p.

[43] FAO (2005) State of the World's Forests. 17 p. http://www.fao.org/3/a-y5574e.pdf

[44] Goula, B.T., Brou, K., Brou, T., Savane, I., Vamoryba, F. and Bernard, S. (2007) Estimation des pluies exceptionnelles journalières en zone tropicale, cas de la Côte d'Ivoire par comparaison des lois Log normale et de Gumbel. Journal des Sciences Hydrologiques, 52, 49-67. https://doi.org/10.1623/hysj.52.1.49

[45] Soro, G.E. (2011) Modélisation statistique des pluies extrêmes en Côte d'Ivoire. Thèse Unique, Université Nangui Abrogoua, Abidjan, 173 p.

[46] Djaha, J.B.A., N'da, A.A.A., Koffi, E.K., Ballo, C.K. and Coulibaly, M. (2012) Croissance et aptitude au greffage de deux génotypes d'anacardier (Anacardium occidentale L.) élites utilisées comme porte-greffe en Côte d'Ivoire. International Journal of Biological and Chemical Sciences, 6, 1453-1466. http://ajol.info/index.php/ijbcs https://doi.org/10.4314/ijbcs.v6i4.5

[47] Barry, A.A., Caesar, J., Tank, A.M.G.K., Aguilar, E., McSweeney, C., Cyrille, A.M., Nikiema, M.P., Narcisse, K.B., Sima, F., Stafford, G., Touray, L.M., Ayilari-Naa, J.A., Mendes, C.L., Tounkara, M., Gar-Glahn, E.V.S., Coulibaly, M.S., Dieh, M.F., Mouhaimouni, M., Oyegade, J.A., Sambou, E. and Laogbessi, E.T. (2018) West Africa Climate Extremes and Climate Change Indices. International Journal of Climatology, 38, e921-e938. https://doi.org/10.1002/joc.5420

[48] AISA (2019) Association Ivoirienne des Sciences Agronomiques. 10 p. https://pratik.ci/annuaire

[49] Anonymous (2019) Les données climatiques pour les villes du monde entier, Climat Côte d'Ivoire: Pluviométrie, Température moyenne Côte d'Ivoire. $14 \mathrm{p}$.

https://fr.climate-data.org/afrique/cote-d-ivoire-134/

[50] Berka, S. and Abdelkader, H. (2001) Effets de quelques traitements physico-chimiques et de la température sur la faculté germinative de la graine d'Arganier. Revue Forestière Française, 53, 125-130. https://doi.org/10.4267/2042/5219

[51] Diatta, S., Salifou, I., Sy, M.O., Kabore-Zoungrana, C.Y., Banoin, M. and Akpo, L.E. (2009) Évaluation des potentialités germinatives d'un ligneux fourrager sahélien, Maerua crassifolia Forssk., Capparaceae. 1-11. http://www.irrd.org

[52] Zerbo, P., Belem, B., Mllogo-Rasolodimby, J. and Van, D.P. (2010) Germination 
sexuée et croissance précoce d'Ozoroainsignis Del., une espèce médicinale du Burkina Faso. Cameroon Journal of Experimental Biology, 6, 74-80. https://doi.org/10.4314/cajeb.v6i2.68524

[53] Gorgon, I.T., Olga, D.Y., Komla, E.A., Francois, W. and Kouami, K. (2015) Essai de germination et de croissance au stade juvénile des souches locales de Jatropha curcas en république centre africaine. European Scientific Journal, 11, 260-276.

[54] N'golo, B., Noufou, D.O., Djézou, K., Adama, B. and Fezan, H.T. (2018) Effets de cinq prétraitements sur la germination du vène (Pterocarpus erinaceus Poir., Fabaceae) dans la Réserve du Haut Bandama (Côte d'Ivoire). European Scientific Journal, 14, 438. https://doi.org/10.19044/esj.2018.v14n30p438

[55] Douma, S., Adamou, M.M., Aboubacar, K., Alleidi, I. and Boubacar, A.N. (2019) Effet du régime d'irrigation sur la germination et la croissance en pépinière de Parkia biglobosa (Jacq.) G. Don. Journal of Animal and Plant Sciences, 40, 6573-6583. http://www.m.elewa.org/JAPS

[56] Thiombiano, A., Wittig, R. and Guinko, S. (2003) Conditions of Sexual Multiplication in Some Combretaceae in Burkina Faso. Revue d Ecologie-la Terre et la Vie, 58, 361-379.

[57] Ameri, A.H. andDaldoum, A.M.D. (2017) Effect of Different Pretreatment Methods and Materials on Germination Potential of Faidherbia albida Seeds. Scholars Journal of Agriculture and Veterinary Sciences, 4, 86-90.

[58] Giordano, E. (1972) Interaction de la sélection et de la culture intensive. Unasylva, 97-98, 82-88.

[59] Salazar, R. and Quesada, M. (1987) Provenance Variation in Guazuma ulmifolia L. in Costa Rica. Commonwealth Forestry Review, 66, 317-324.

[60] Dianda, M. and Chalifour, F.P. (2002) Effets du N minéral et du génotype de la plante sur la croissance et la nodulation de Faidherbia albida. Canadian Journal of Botany, 80, 241-254. https://doi.org/10.1139/b01-145

[61] Maranz, S. and Wiesman, Z. (2003) Evidence for Indigenous Selection and Distribution of the Shea Tree, Vitellaria paradoxa, and Its Potential Significance to Prevailing Parkland Savanna Tree Patterns in Sub-Saharan Africa North of the Equator. Journal of Global Biogeography, 30, 1505-1516.

https://doi.org/10.1046/j.1365-2699.2003.00892.x

[62] Soloviev, P., Niang, T.D., Gaye, A. and Totte, A. (2004) Variabilité des caractères physicochimiques des fruits de trois espèces ligneuses de cueillette, récoltés au Sénégal, Adansonia digitata, Balanites aegyptiaca et Tamarindus indica. Fruits, 59, 109-119. https://doi.org/10.1051/fruits:2004011

[63] Assogbadjo, A.E., Sinsin, B., Codjia, J.T.C. and Van Damme, P. (2005) Ecological Diversity and Pulp, Seed and Kernel Production of the Baobab (Adansonia digitata) in Benin. Belgian Journal of Botany, 138, 47-56.

[64] Assogbadjo, A.E., Kyndt, T., Sinsin, B., Gheysen, G. and Van Damme, P. (2006) Patterns of Genetic and Morphometric Diversity in Baobab (Adansonia digitata L.) Populations across Different Climatic Zones of Benin (West Africa). Annals of Botany, 97, 819-830. https://doi.org/10.1093/aob/mcl043

[65] Dianda, M., Bayala, J., Diop, T. and Ouédraogo, S.J. (2009) Improving Growth of Shea Butter Tree (Vitellaria paradoxa C.F. Gaertn.) Seedlings Using Mineral N, P and Arbuscular Mycorrhizal (AM) Fungi. Biotechnologie, Agronomie, Société et Environnement, 13, 93-102.

[66] Sambe, M.A.N., Sagna, M. and Sy, M.O. (2010) Seed Germination and in Vitro 
Plant Regeneration of Parkia biglobosa (Jacq.) Benth. African Journal of Biotechnology, 9, 3099-3108.

[67] FAO (1992) Guide de manipulation des semences forestières. Etude FAO forêt 20/2. 20 p. http://www.fao.org/docrep/006/AD232F/AD232F00.HTM

[68] Laurie, M.V. (1974) Tree Planting Practices in African Savannas. Food and Agriculture Organization of the United Nations, Rome, 42-43.

[69] Naidu, C.V. and Rajendrudu, G. (2001) Influence of Kinetin and Nitrogenous Salts on Seed Germination of Red Sanders (Pterocarpus santalinus Linn. f.). Seed Science and Technology, 29, 669-672.

[70] Zhang, C.Y., et al. (2015) Soaking, Temperature, and Seed Placement Affect Seed Germination and Seedling Emergence of Litchi chinensis. HortScience, 50, 628-632. https://doi.org/10.21273/HORTSCI.50.4.628

[71] Kolodziejek, J. (2017) Effect of Seed Position and Soil Nutriments on Seed Mass, Germination and Seedling Growth in Peucedanum oreoselinum (Apiaceae). Scientific Reports, 7, Article No. 1959. https://doi.org/10.1038/s41598-017-02035-1

[72] Gnanglè, P.C.R., Glele, K., Oumorou, M., N'djolosse, K., Bonou, W. and Sokpon, N. (2010) Tests de croissance de jeunes plants de néré (Parkia biglobosa, Jack, R. Br.) en pépinière. International Journal of Biological and Chemical Science, 4, 1939-1952. https://doi.org/10.4314/ijbcs.v4i6.64945

[73] Esmaeilpour, A. and Van, P. (2016) Evaluation of Seed Soaking Times on Germination Percentage, Germination Rate and Growth Characteristics of Pistachio Seedlings. Acta Horticulturae, 1109, 107-112. https://doi.org/10.17660/ActaHortic.2016.1109.17

[74] Sanjay, S., Ranjana, B., Varghese, S.K. and Naithani, S.C. (2008) Effect of Hot-Water Treatment on Seed Germination of Some Fast Growing Tropical Tree Species. Journal of Tropical Forestry, 24, 49-53.

[75] Repoblika, M. (1963) Introduction de Khaya senegalensis (Caïlcedra) ou acajou du Sénégal au Madacascar. Fahafahana-Tanindrazana-Fandrosoana. 15 p. https://uses.plantnet-project.org/fr/Khaya senegalensis (PROTA)

[76] Ahoton, L.E., Adjakpa, J.B., M’po, I.M. and Akpo, E.L. (2009) Effet des prétraitements des semences sur la germination de Prosopis africana (Guill., Perrot et Rich.) Taub., (Césalpiniacées). Tropicultura, 27, 233-238. 